\title{
Smečované podání u volejbalistů kategorie kadetů
}

\section{Spike serve in cadet volleyball players}

\author{
František Zahálka ${ }^{1}$,Tomáš Malý', Miroslav Čada², Lucia Malá ${ }^{1}$ \\ ${ }^{1}$ Fakulta tělesné výchovy a sportu Karlovy univerzity, Praha \\ ${ }^{2}$ Fakulta sportovních studií Masarykovy univerzity, Brno
}

\begin{abstract}
Abstrakt:
Cílem studie bylo zjistit vztah rychlosti smečovaného podání, dosahem při kontaktu s míčem a modelovou výškou výskoku jako ukazatele explozivni síly dolních končetin, a tyto hodnoty vzájemně korelovat.

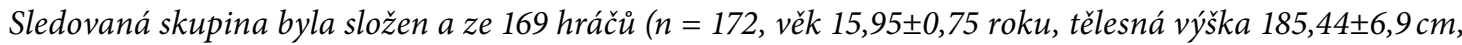

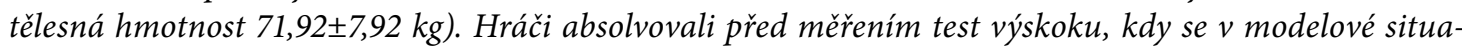
ci snažili po rozběhu docílit maximální výšky výskoku. Průměrná rychlost podání byla 79,4 $\pm 9,4 \mathrm{~km} . \mathrm{h}^{-1}$. Nejrychlejši podání mělo hodnotu 105,9 km. $h^{-1}$, nejpomalejší 56,3 km.h. (rozdíl 46,8\%). Ze získaných maximálních hodnot byly vytvořeny procentilové normy (padesátý percentil $P_{50}=79,9 \mathrm{~km} \cdot \mathrm{h}^{-1}$ ). Procentilové rozložení pro rychlosti smečovaného podání a výskoku umožňuje vzhledem k relativně vysokému počtu naměřených hráčù vzít uvedené hodnoty jako normativní, a porovnávat tak dalši hráče. Ukazuje se, že korelace výšky výskoku je dobrým ukazatelem dispozice $k$ realizaci smečovaného podání vzhledem $k$ dosažené rychlosti míče.
\end{abstract}

\begin{abstract}
:
The aim of the study was to determine the relationship between jump serve velocity achieved in contact with the ball and a model height of the jump as an indicator of explosive strength of lower extremities and to correlate these values. The monitored group consisted of 169 players $(n=172$, age $15.95 \pm 0.75$ year, body height $185.44 \pm 6.9 \mathrm{~cm}$, body weight $71.92 \pm 7.92 \mathrm{~kg}$ ). Before the measurement, the players undertook a jump test, when, in a model situation, they attempted to achieve maximum jump height after a run-up. The highest serve velocity value was $105.9 \mathrm{~km} . \mathrm{h}^{-1}$, while the lowest value was $56.3 \mathrm{~km} . \mathrm{h}^{-1}$ (difference by 46.8 $\%)$. The measured maximum values were transformed into percentile norms $\left(50^{\text {th }}\right.$ percentile $P_{50}=79.9 \mathrm{~km} . \mathrm{h}$ $\left.{ }^{1}\right)$. Percentile distribution for jump serve velocity and the jump enables us, with respect to a relatively high number of tested players, to consider the stated values as normative and to compare other players, as well. It appears that the correlation of jump height is a good indicator of the dispositions for jump serve implementation in terms of the ball velocity.
\end{abstract}

Kličová slova: $\quad$ diagnostika, rychlostní schopnosti, sportovní hry, sport mládeže

Key words: $\quad$ diagnostic, speed abilities, sports games, youth sports

Studie vznikla za podpory MSM 0021620864 a GAČR 407/11/P784.

\section{ÚVOD}

Za jednu z významných charakteristik současného mládežnického i profesionálního sportu můžeme považovat neustále se zvyšující nároky na rychlostní schopnosti. Zvláště v kolektivních sportovních hrách jsou rychlostní schopnosti a jejich projev častokrát limitujícím faktorem sportovního výkonu a úspěšnosti celého družstva. Předpokladem úspěšnosti je však realizace pohybové úlohy nejen maximální rychlostí, ale i správným technickým provedením nebo optimálním výběrem taktické varianty. Lokomočních činností acyklického charakteru je v kolektivních sportovních hrách velké množství. Jednou ze základních dovedností každého volejbalového hráče je podání. Vytvoření ofenzivní situace hned při zahájení hry je jedním ze základních úkolů podávajícího hrá- 
če. Podání se ve volejbale už dávno nepokládá jen za zahájení hry, ale má v moderním pojetí dvě základní úlohy (Haník 2007): dosáhnout přímý bod, resp. způsobit soupeřovi zásadní těžkosti s rozvinutím ofenzivy (možnost rychlých útočných kombinací), a vyhrát souboj o čas, čímž se soupeřovi zkomplikuje jeho ofenzivní činnost, a vzniká tím dostatek času pro rozvinutí vlastní činnosti defenzivní. Účinnost podání ve volejbale závisí na precizním zvládnutí kinematických (časově-prostorových) a dynamických (př́ičinně-silových) charakteristik. Podání ve volejbalu je individuální činnost, na jejíz realizaci nemají vliv spoluhráči ani protihráči. V kategorii mužského volejbalu jednoznačně dominuje smečované podání z výskoku (Rodríguez et al. 2007). Při tomto typu podání je míči je udělena výrazná rotace, což spolu s vlastní rychlostí míče vytváří problémy soupeřovi při př́ijmu a na přihrávce (Huang; Hu 2007). Rozdíl rychlostí mezi smečovaným a plachtícím podáním (ze země a z výskoku) představuje 5,7 m.s $\mathrm{s}^{-1}$ (26,8 \%). Huang; Hu (2007) u elitních mužských hráčů uvádějí rozdíl rychlostí mezi smečovaným a plachtícím podáním $5,7 \mathrm{~m} \cdot \mathrm{s}^{-1}(22,4 \%)$. Rodríguez a kol. (2007) uvádí rozdíl 17,9\%. Moras et al., (2008) uvádí rozdíl u elitních hráčů až 11,56 m.s.1 (100,8 \%) na základě sledovaných 377 podaní realizovaných při olympijské kvalifikaci. Vztah mezi účinností podání k jeho typu a rychlosti u vrcholových volejbalistů nebyl prokázán. Rodríguez et al., (2007) ve svém výzkumu při čtyřech zápasech olympijské kvalifikace uvádí v mužském vrcholovém volejbale jednoznačnou dominanci smečovaného servisu (84,9\%) oproti plachtícímu servisu ve výskoku $(9,5 \%)$, resp. ze země $(5,6 \%)$. Při rozdělení úspěšnosti podání do 5 kategorií nezjistili vztah mezi úspěšností servisu a rychlostí podání. Smečovaný servis se pohyboval v intervalech 23,1 až $28,1 \mathrm{~m} . \mathrm{s}$ ${ }^{1}$ pro všechny kategorie úspěšnosti. Přidal (2001) zjistil, že v kategorii kadetů na reprezentační úrovni závisí úspěšnost družstva od kvality realizace herní činnosti jednotlivce, jako je podání. Ukázalo se, že vítězná družstva dostávají častěji pod tlak poražená družstva v prŕípadě, kdy převládá účinné podání hodnocené stupněm 1, 2 a 3 z 5stupňové hodnotící škály (Data Volley). V literatuře se objevuje minimální množství informací věnujících se sledování rychlosti podání, resp. biomechanickým charakteristikám v mladší hráčské kategorii, jako je např. kategorie kadetů. Většina výzkumů se zabývá kategorií seniorskou (Coleman 1997, Forthomme et al. 2005, Huang; Hu 2007, Lehnert et al. 2003, Moras et al. 2008), resp. žen (Malý et al. 2009). U seniorské kategorie lze předpokládat ustálený pohybový projev, který lze z hlediska edukace již měnit velmi složitě. Proto je velmi zajímavé sledovat úroveň rychlosti podání a její distribuci spolu s doplňkovými motorickými projevy a předpoklady především u mladších hráčů, v tomto případě u kategorie kadetů. Dobrý předpoklad explozivní síly dolních končetin vytváří základ pro efektivní realizaci výskoku, který je pro následný úder do míče jedním ze základních podmínek. Každou pohybovou dovednost je totiž potřebné si osvojit již v mladém věku a průběhu dalších let na ní pracovat a efektivněji rozvíjet.

\section{METODIKA}

Sledovaná skupina byla složena ze 169 hráčů $(n=172$, věk $15,95 \pm 0,75$ roku, tělesná výška $185,44 \pm 6,9 \mathrm{~cm}$,

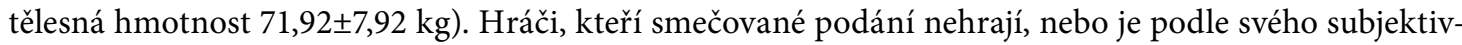
ního posouzení nezvládají, podávali ze země. Každý hráč podával třikrát po sobě a rychlost podání byla měřena pomocí radarového systému STALKER ATS. Radar je schopen měřit rychlost předmětu v rozsahu $8-480 \mathrm{~km} \cdot \mathrm{h}^{-1} \mathrm{~s}$ přesností $0,1 \mathrm{~km} \cdot \mathrm{h}^{-1}$.

Kolmo na osu rozběhu byla umístěna digitální kamera pro snímání a následné vyhodnocení plošných parametrů jako jsou délka kroku, výška výskoku, dosah ruky při kontaktu s míčem a délka letu. Dvě kamery zabíraly hrací pole pro hodnocení místa dopadu míče z podání (Janura; Zahálka 2004). Všichni hráči absolvovali před měřením test výskoku, kde se v modelové situaci snažili po rozběhu docílit maximální výšky výskoku. Test byl prováděn pro evaluaci silově explozivních schopností dolních končetin jako základního předpokladu pro realizaci efektivního vertikálního výskoku. Byl hledán vztah mezi uvedeným testem vertikálního výskoku a rychlostí míče při smečovaném podání, kde se předpokládá, že vlastní výška výskoku při reálném podání je více podmíněna koordinací technicky složité pohybové činnosti. Techniku smečovaného podání lze rozdělit na několik fází: nadhoz, rozběh, odraz, let, úder a dopad (Obrázek 1). Tyto fáze na sebe navazují, prolínají se, ale hlavně se navzájem ovlivňují. 


\section{Nadhoz}

Nadhoz je první a dá se říci, že jednou z nejdůležitějších fází celého pohybu. Pouze správně provedený nadhoz spolu se správným časováním umožní hráči kontakt s míčem v optimální poloze těla a švihové paže během letu. Optimalizace nadhozu spočívá v provádění pohybu stejnou silou po shodné dráze a ve vypouštění míče ve stále stejné poloze. Pouze dodržení těchto výchozích předpokladů zajistí jak dodržení stejné dráhy letícího míče, tak i jeho stejnou rychlost, což má za následek, že míč dorazí na dané místo v prostoru pokaždé stejně a hráč nemusí svůj pohybový a časový stereotyp během pohybu korigovat v závislosti na situaci. Hráč si nadhazuje míč bud’ jednou nebo oběma rukama. Častějším typem provedení je nadhoz z jedné ruky, a to z ruky švihové paže, tedy z té, která později provádí úder. Pro provedení nadhozu jednou rukou hovoří i princip vzájemně protisměrného pohybu dolních a horních končetin (to si lze představit na př́kladu, kdy při vykročení pravou nohou jde vpřed i levá). Konkrétně tedy pravák nadhazuje míč pravou rukou, mírně vpředu je celá jeho pravá polovina těla, tedy jeho pravé rameno a nakročená pravá noha. To lze považovat za výhodnější vzhledem k poloze těla a zahájení pohybu vpřed. Další z důležitých parametrů je udělení rotace míči. Při nadhozu jednou rukou dostává míč rotaci v závěrečném oblouku pohybu paže, a to především z pohybu dlaně a prstů. Při nadhozu obouruč je rotace předávána bud' jen tou rukou, která drží míč více zespodu, nebo prsty obou rukou v př́padě, kdy je míč držen symetricky ze stran. $Z$ uvedeného se jeví jako optimální nadhoz z jedné ruky, při němž se vyskytují nejlepší předpoklady vyhodit míč v ose pohybu těla, použití dominantní paže zaručuje větší shodu v síle a směru vyhození, stejně tak jako udělení rotace dlaní a prsty ruky. Rotace míče kolem horizontální osy je nezbytnou podmínkou pro změnu dráhy letícího míče tak, aby i při velmi vysokých rychlostech dopadl do hřiště.

\section{Rozběh}

Další fází je rozběh, kdy hráč získává nezbytnou kinetickou energii. Fáze nadhozu končí v posledním momentu kontaktu ruky či konečků prstů s míčem, ale fáze rozběhu začíná již zmiňovanou polohou těla při nadhozu. Pro zjednodušení bude pohyb dále popsán na hráči provádějícím úder pravou rukou. V okamžiku, kdy je poloha švihové pravé paže během nadhozu v úrovni hrudníku, dochází k vykročení levé dolní končetiny vpřed. První startovací krok není nijak dlouhý. Odraz z levé nohy je již podstatně delší s výraznou bezoporovou fází a při kontaktu pravé dolní končetiny s podložkou je v ideálním případě tato noha s maximální extenzí v koleně. Po došlapu pravé dolní končetiny dochází k jejímu pokrčení, což je okamžik, kdy se zahajuje transformace horizontálního impulzu na vertikální. Zde hráč k silově odrazovým schopnostem dolních končetin přidává energii získanou během rozběhu.

\section{Odraz}

Ve chvíli, kdy levá dolní končetina míjí dolní končetinu, jež došlapuje, je výška těžiště těla minimální, poté již dochází ke zvedání těla, po došlapu levé nohy se zvedání urychluje a následuje opuštění podložky. Popsaný mechanizmus odpovídá tzv. „brzdnému dvojkroku“, který se provádí u klasického odrazu při smeči. Tato technika odrazu se pro smečované podání jeví jako vhodnější oproti technice odrazu „předskokem“, tedy odrazem po doskoku na obě nohy, jelikož při ní dochází ke zbrzdění pohybu plynulejším způsobem. Tím, že je poslední krok, či vlastně let, dostatečně dlouhý, je rozdíl mezi maximální a minimální výškou těžiště menší, než by tomu bylo u odrazu po doskoku na obě dolní končetiny.

\section{Let}

Fáze letu začíná při opuštění podložky nohama a končí dopadem. Během letu již hráč nemůže získat žádnou energii a hospodaří pouze s tou, kterou získal při rozběhu a odrazu. Během odrazu vykonávají obě paže pohyb směrem vzhůru, a aktivně tak napomáhají zvedání celého těla a dosažení vyššího výskoku. V letové fázi jdou paže do protipohybu, při kterém se smečující paže dostává za záda do švihové polohy.

\section{Úder}

Během letu se provádí nejdůležitější část celého pohybového cyklu, kterou je kontakt ruky s míčem. V okamžiku styku ruky s míčem by hráč měl mít paži napjatou v lokti a těžiště těla by mělo být na vrcho- 
lu své letové dráhy. Tento okamžik je měřitelný v setinách vteřiny, a v takto krátkém okamžiku musí hráč udeřit do nadhozeného míče. Nestejně nadhozený míč může způsobit, že je hráč donucen provést úder ve chvíli, kdy jeho tělo ještě stoupá po letové křivce, nebo naopak, kdy již klesá; případně je nucen měnit polohu paže během švihu. Ve chvíli, kdy hráč vyhodnotí svůj nestejný nadhoz ještě během rozběhu nebo odrazu, musí provést časové korekce, které mohou mít za následek pouze snížení dosažitelné energie, což se projeví v rychlosti pohybu těla, síle odrazu či výšce výskoku.

\section{Dopad}

Dopad následuje po úderu míče a nemá na celkový pohyb vliv. Měl by být proveden na obě mírně pokrčené dolní končetiny. Dopad lze pouze hodnotit jako výsledek předchozí činnosti. Může prozradit chyby v pohybovém cyklu, které pak mají za následek dopad na jednu dolní končetinu, do záklonu nebo předklonu, nesourodé polohy paží okolo těla apod.

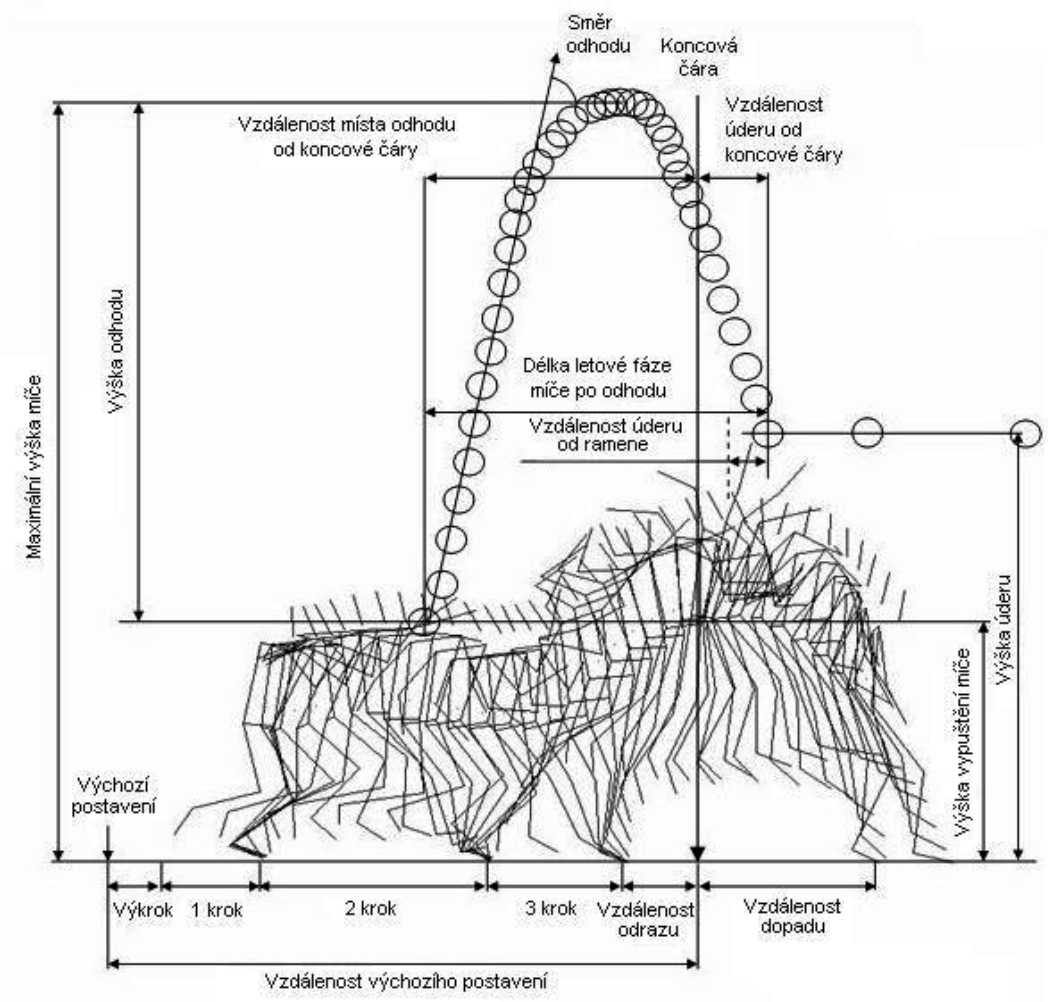

Obrázek 1: Kinogram podání z výskoku se základními kinematickými parametry.

Pro statistické zpracování výsledků jsme použili aritmetický průměr, směrodatnou odchylku, Pearsonovu součinovou korelaci a procentilové normy. Procentil udává, kolik procent výkonů v testovaném souboru je nižších než aktuální výkon (Měkota; Blahuš 1983). Data jsme zpracovali pomocí statistického softwaru IBM SPSS 19.0.

\section{VÝSLEDKY}

Průměrná rychlost podání byla $79,4 \pm 9,4 \mathrm{~km} \cdot \mathrm{h}^{-1}$. Nejrychlejší podání jsme zaznamenali s hodnotou $105,9 \mathrm{~km} \cdot \mathrm{h}^{-1}$ a nejpomalejší $56,3 \mathrm{~km} \cdot \mathrm{h}^{-1}$. Rozdíl mezi nejrychlejším a nejpomalejším podáním představuje 46,8\%. Ze získaných maximálních hodnot od všech hráčů jsme vytvořili procentilové normy (Tabulka 1). Prostřední hodnota rozdělující horních a dolních $50 \%$ výkonů je stanovená padesátým percentilem $\mathrm{P}_{50}=79,9 \mathrm{~km} \cdot \mathrm{h}^{-1}$. 
Tabulka 1: Procentilové rozdělení rychlosti podání u sledované skupiny (n=169)

\begin{tabular}{|l|c|c|c|c|c|c|c|c|c|}
\hline Procentily & $\mathrm{P}_{10}$ & $\mathrm{P}_{20}$ & $\mathrm{P}_{30}$ & $\mathrm{P}_{40}$ & $\mathrm{P}_{50}$ & $\mathrm{P}_{60}$ & $\mathrm{P}_{70}$ & $\mathrm{P}_{80}$ & $\mathrm{P}_{90}$ \\
\hline Rychlost podání $\left(\mathrm{km} \cdot \mathrm{h}^{-1}\right)$ & 67 & 72 & 74 & 77 & 80 & 83 & 84 & 86 & 90 \\
\hline
\end{tabular}

Nejvyšší četnost (zastoupení) rychlostí podání byla zjištěna $\mathrm{v}$ intervalu mezi 83,3 - 86,6 km.h-1 (Obrázek 2).

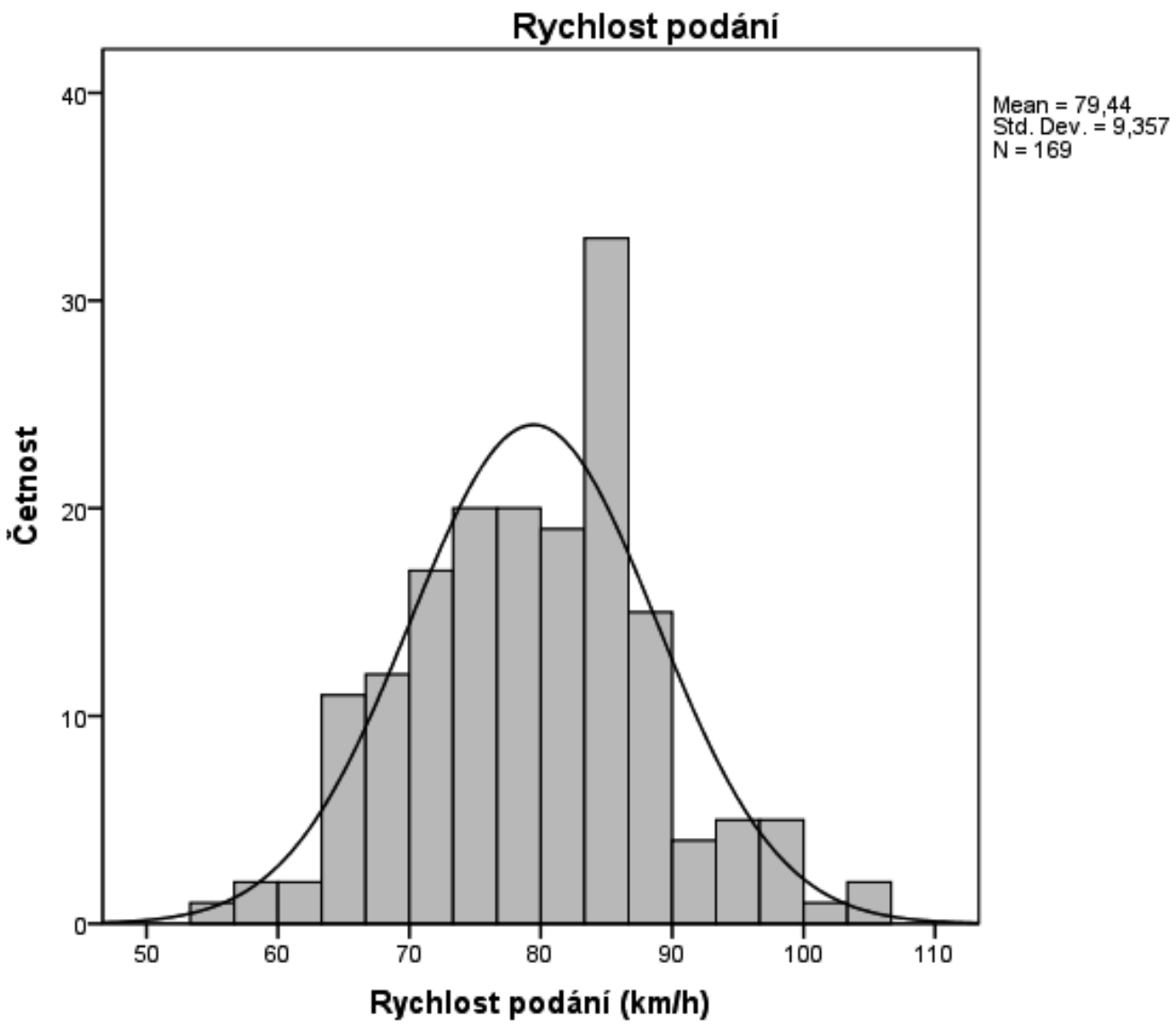

Obrázek 2 Distribuce rychlostí podání (maximální hodnoty)

Hodnocení výšky výskoku po rozběhu prokázalo průměrnou hodnotu $\mathrm{h}=68,8 \pm 8,4 \mathrm{~cm}$. Nejlepší zaznamenaný výkon byl $92 \mathrm{~cm}$ a nejhorší $39 \mathrm{~cm}$. Rozsah výšky výskoku tak představoval $53 \mathrm{~cm}(57,6 \%)$. Procentilové normy jsou uvedené v tabulce 2 . Střed procentilové stupnice byl určen výkonem $\mathrm{P}_{50}=69 \mathrm{~cm}$.

Tabulka 2 Procentilové rozdělení výšky výskoku po rozběhu u sledované skupiny (n=169)

\begin{tabular}{|l|c|c|c|c|c|c|c|c|c|}
\hline Procentily & $\mathrm{P}_{10}$ & $\mathrm{P}_{20}$ & $\mathrm{P}_{30}$ & $\mathrm{P}_{40}$ & $\mathrm{P}_{50}$ & $\mathrm{P}_{60}$ & $\mathrm{P}_{70}$ & $\mathrm{P}_{80}$ & $\mathrm{P}_{90}$ \\
\hline Výška výskoku $(\mathrm{cm})$ & 60 & 63 & 65 & 67 & 69 & 71 & 73 & 76 & 79 \\
\hline
\end{tabular}


Rychlost podání u sledované skupiny signifikantně korelovala s výškou výskoku po rozběhu $(\mathrm{r}=0,46$; $\mathrm{p}<0,01)$. Vztah mezi sledovanými proměnnými je znázorněn na Obrázku 3.

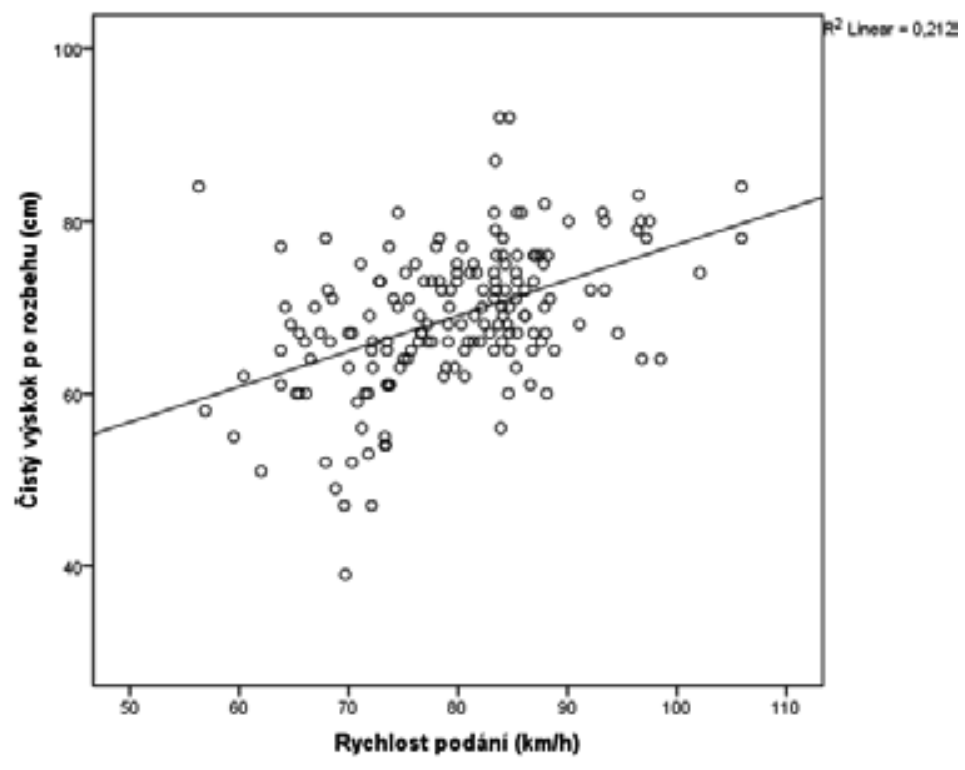

Obrázek 3 Vztah mezi rychlostí podání a výškou výskoku po rozběhu u sledovaných hráčů

\section{DISKUZE}

Pokud zhodnotíme sledovaný vzorek hráčů, převažovali hráči se správnou švihovou paží, hráčů s levou švihovou paží bylo pouze šest, což znamená 3,6\%. U sledovaných nadhozů dominovalo provedení rukou shodnou se švihovou paží, obouručně nadhazovalo 26 hráčů, což znamená $15,4 \%$. Čtyři hráči dokonce nadhazovali opačnou rukou než je jejich švihová paže. Je potřebné připomenout, že snaha o maximální shodu každého nadhozu se týká také místa, odkud hráč nadhazuje. Při hodnocení činností spojených se smečovaným podáním celé sledované skupiny se ukázalo, že intraindividuální stabilita provedení je velmi vysoká, což dokumentuje, že hráči mají tuto pohybovou činnost ve svém věku již dobře zafixovanou. To lze pozorovat jak u hráčů s kvalitně realizovaným podáním, tak i u provedení ne tak povedených. Při sledování interindivuální stability je naopak patrný značný rozptyl, a to u všech sledovaných parametrů. Absolutní dosažená rychlost nemůže být nejdůležitějším kriteriem, protože je zapotřebí hodnotit, bylo-li podání úspěšné. Jako př́klad lze uvést, že tři hráči dosáhli absolutní maximální rychlosti přes $100 \mathrm{~km} \cdot \mathrm{h}^{-1}$ (dvakrát $106 \mathrm{~km} \cdot \mathrm{h}^{-1}$ a jednou $102 \mathrm{~km} \cdot \mathrm{h}^{-1}$ ), a to úspěšným podáním. Nejrychlejší podání, které mířilo do sítě, mělo rychlost $97,2 \mathrm{~km} \cdot \mathrm{h}^{-1}$, a nejrychlejší, které šlo do autu, rychlost $99,6 \mathrm{~km} . \mathrm{h}$ ${ }^{1}$. Rozptyl rychlostí u všech odehraných podání byl v intervalu $56,3 \mathrm{~km} \cdot \mathrm{h}^{-1}-105,9 \mathrm{~km} \cdot \mathrm{h}^{-1}$. Tento obrovský rozdíl v dosažených rychlostech je způsoben velmi odlišným stupněm zvládnutí dané techniky. Zde je možné dokázat, že intraindividuální charakteristiky jsou konzistentní, jelikož nejhoršího výsledku dosáhl hráč s průměrnou rychlostí podání $52,6 \mathrm{~km} \cdot \mathrm{h}^{-1}$, jehož jednotlivé pokusy měly hodnoty $49,9 \mathrm{~km} . \mathrm{h}$ ${ }^{1}, 51,7 \mathrm{~km} \cdot \mathrm{h}^{-1}$, a $56,3 \mathrm{~km} \cdot \mathrm{h}^{-1}$. Dva pokusy byly do sítě, třetí pak do autu. Naopak u dvojice nejlepších byl průměr rychlostí 93,8 km.h-1 $\left(75,4 \mathrm{~km} \cdot \mathrm{h}^{-1}, 100 \mathrm{~km} \cdot \mathrm{h}^{-1}, 106 \mathrm{~km} \cdot \mathrm{h}^{-1}\right)$ a 95,4 km.h ${ }^{-1}\left(91,2 \mathrm{~km} \cdot \mathrm{h}^{-1}, 89 \mathrm{~km} \cdot \mathrm{h}^{-1}\right.$, $\left.106 \mathrm{~km} \cdot \mathrm{h}^{-1}\right)$. Z uvedených podání byl jeden pokus do sítě a jeden do autu. K celkové rychlosti míče ještě přispívá rychlost pohybu celého těla. Úhlové rychlosti jednotlivých částí horní končetiny závisí na svalovém úsilí příslušných svalových skupin. Toto úsilí je regulované nutností kontroly směru nárazu ruky do míče vzhledem k podmínce shodného směru pohybu míče. Důležitým aspektem je zpevnění distálních částí horní končetiny v momentě úderu. Síla úderu je ovlivněna také deformací ruky při úderu. $Z$ toho důvodu je zapotřebí zvláště u mladších hráčů věnovat velkou pozornost cvičením, která napomáhají pevnosti ruky př́slušných svalových skupin a vazů, které zabraňují a zmírňují uvedenou deforma- 
ci. Podobný prŕklad byl potvrzen např. u hráčů fotbalu při sledování maximální rychlosti kopu př́mým nártem (Lees; Nolan 1998, Nunome et al. 2006). Při hodnocení úspěšnosti podání bylo 257 pokusů umístěno do pole, což znamená 50,7 \% ze všech 507 odehraných podání. Počet podání do sítě byl 103 (20,3\%) a počet do autu 156 (30,2 \%). Při hodnocení úspěšnosti každého hráče bylo zjištěno, že 29 hráčủ neprovedlo úspěšné podání ani jednou, 56 hráčů mělo úspěšný alespoň jeden pokus, 60 hráčů mělo úspěšné pokusy dva a 27 hráčů mělo úspěšné všechny tři pokusy.

Rychlost podání u sledované skupiny signifikantně korelovala s výškou výskoku po rozběhu. Coleman (1997) sledoval pomocí 3D analýzy rotovaný servis z výskoku u reprezentantů Velké Británie $(\mathrm{n}=11)$. Bylo zjištěno, že s rychlostí udeřeného míče bezprostředně koreluje maximální flexe loketního kloubu a úhlová rychlost kloubu ramenního, stejně jako rychlost ruky při úderu. Forthomme et al. (2005) uvádí signifikantní vztah mezi rychlostí útočného úderu a těmito parametry: maximálním momentem síly dosaženým při vnitřní rotaci dominantního ramenního kloubu při koncentrické síle, maximálním momentem síly při flexi a extenzi loketního kloubu dominantní končetiny, výškou úderu při smeči, týdenním počtem tréninkových hodin zaměřených na silový trénink a BMI indexem hráčů.

Dalším z hodnocených parametrů byla poloha nohou při odrazu. Správná poloha nohou dovoluje provést odraz efektivním způsobem, kdy plynule probíhá transformace horizontálního impulzu na vertikální. Hodnocení vzdálenosti nohou od sebe bylo prováděno plošnou 2-D analýzou, kdy je vzdálenost nohou brána jako jejich průmět v rovině XY, takže pokud hráč stojí čelem $\mathrm{k}$ síti a má nohy vedle sebe, je jejich vzdálenost jako průmět $\mathrm{v}$ rovině XY rovna nule. Rozptyl takto posuzované vzdálenosti nohou byl u všech sledovaných pokusů v intervalu $1-117 \mathrm{~cm}$. Průměrná vzdálenost byla $70,5 \mathrm{~cm}$. Tak široké rozpětí je způsobeno tím, že se pro odraz používají oba dva druhy dokroků, a to „brzdící dvojkrok“ a "př̌edskok“. Zvláště při druhém způsobu je položení nohou blíže k sobě, což ovlivňuje celkové hodnocení. Pro posouzení výšky výskoku se hodnotila výška hlavy v okamžiku kontaktu ruky s míčem. Naměřené hodnoty se pohybovaly $\mathrm{v}$ rozmezí $190-256 \mathrm{~cm}$ s průměrnou hodnotou $226 \mathrm{~cm}$. Tento parametr je ovlivněn tím, že v okamžiku kontaktu ruky s míčem může být tělo hráče na vzestupné nebo sestupné dráze svého letu, to podle polohy nadhozeného míče. Stejně velké rozpětí je zaznamenáno i u hodnot výšky kontaktu ruky s míčem. Hodnoty byly v intervalu $236-312 \mathrm{~cm}$ s průměrnou hodnotou 227. Mezi těmito naměřenými hodnotami není lineární vztah, přestože byly měřeny ve stejném časovém okamžiku. To je způsobeno tím, že někteři hráči opět řeší problém nestejně nadhozeného míče pokrčením paže, nebo úderem mírně před tělem, či dokonce za sebou. Při hodnocení těchto parametrů se nejvíce ukázalo, jak málo hráčů si dokáže správně nadhodit míč a jak důležitou činností nadhoz je. Jedním z hodnotících parametrů byla vzdálenost nohou od koncové čáry hřiště v okamžiku odrazu. Hodně hráčů nadhazuje a po rozběhu se následně odráží ve větší vzdálenosti od koncové čáry, aby tak eliminovali málo zakřivenou dráhu letu míče způsobenou nedostatečnou rotací. Odraz byl prováděn v intervalu vzdáleností $12-350 \mathrm{~cm} \mathrm{~s}$ průměrnou hodnotou $178 \mathrm{~cm}$ od koncové čáry. Při hodnocení délky letu hráče vzduchem byla vzdálenost mezi místem odrazu a místem dopadu naměřena v intervalu $8-289 \mathrm{~cm}$ s průměrnou hodnotou délky letu $131 \mathrm{~cm}$. Lze konstatovat, že úroveň zvládnutí dané techniky byla velmi rozdílná od těch, kteří již v tomto věku dosahují takřka „světové“ úrovně, až po ty, kteří pro nesprávné návyky nejsou schopni podání ani provést. Nejlepší světoví hráči dokážou při smečovaném podání dosáhnout rychlosti míče přes 120 $\mathrm{km} \cdot \mathrm{h}^{-1}$ (Lehnert et al. 2003). Ze sledované skupiny měli dva hráči rychlost úspěšného podání $106 \mathrm{~km} . \mathrm{h}^{-1}$, což lze považovat za vynikající výsledek.

\section{Závěr}

Základní myšlenkou celého sledování bylo zjistit rychlost smečovaného podání spolu s výškou výskoku a dosahem při kontaktu s míčem, a ty to hodnoty vzájemně korelovat. Procentilové rozložení pro rychlosti smečovaného podání a výskoku umožňuje vzhledem k relativně vysokému počtu měřených hráčů vzít uvedené hodnoty jako normativní, a porovnávat tak další hráče. Ukazuje se, že korelace výšky výskoku je dobrým ukazatelem dispozice realizace smečovaného podání vzhledem k dosažené rychlosti míče. $\mathrm{Na}$ druhou stranu je výška úderu do míče při vlastním podání zkreslena antropometrickými charakteristikami hráče. Hráči s vyšší tělesnou výškou dosahují vyššího bodu úderu i při relativně nižší výšce 
výskoku. Při vyhodnocování se ukázalo, jak dominantní podmínkou je právě zvládnutí dané techniky. Pouze při jejím kompletním zvládnutí by mělo smysl dávat všechny naměřené hodnoty do souvisejících vztahů. Takto je velmi složité kvantifikovat podíl techniky provedení na parciálních parametrech kinematiky pohybu při smečovaném podání, a především podíl techniky na rychlosti smečovaného míče. Jak již bylo řečeno na začátku, je technika smečovaného podání činností relativně složitou pro mladší hráče. Zatím není $\mathrm{z}$ hlediska metodiky kompletně zvládnuta ani teoreticky a ani prakticky. Některé zde uvedené postřehy by mohly nasměrovat trenéry $\mathrm{k}$ činnostem, kterým je zapotřebí se věnovat během tréninku. Jedná se především o nácvik nadhozu, a to jak pro získání pohybového stereotypu nadhazovacího pohybu, tak i pro stabilní udělení horní rotace nadhazovanému míči. S tím souvisí optimalizace délky rozběhu i odrazu pomocí „brzdného dvojkroku“. Teprve po zvládnutí těchto činností by se mělo přikročit k individuálnímu výběru místa zahájení nadhozu a s ním souvisejícího místa odrazu.

\section{Literatura}

COLEMAN, S. A 3D kinematic analysis of the volleyball jump serve. In Proceedings of the XV International Symposium on Biomechanics in Sports. Denton : Texas Women University, Texas, USA, 1997.

FORTHOMME, B.; CROISER, J.L.; CICCARONE, G.; CRIELAARD, J.M.; CLOES, M. Factors Correlated With Volleyball Spike Velocity. The American Journal of Sports Medicine, 2005, roč. 33, č. 10, s. 1-7.

HANÍK, Z. Podání - základ defenzívy. [online]. 2007, [cit. 2008-6-4]. Dostupné na WWW: <http://hanikvolleyball.cz/cz/clanky/volejbalova-teorie/individualni-herni-cinnosti/ (2007)>.

HUANG, Ch.; HU, L. Kinematic analysis of volleyball jump topspin and float serve. In XXV ISBS Symposium 2007, Ouro Preto, Brazil, 2007.

JANURA, M.; ZAHÁLKA, F. Kinematická analýza pohybu člověka. Olomouc : Univerzita Palackého, 2004.

LEES, A.; NOLAN, L. The biomechanics of soccer: A review. Journal of Sports Sciences, 1998, roč. 16, s. 211-234.

LEHNERT, M.; JANURA, M.; STROMŠÍK, P. The jump serve of the best servers on the Czech national men's volleyball team. International Journal of Volleyball Research, 2003, roč. 6, č. 1, s. 10-13.

MALÝ, T.; ZAHÁLKA, F.; HRÁSKÝ, P.; ČADA, M.; DOVALIL, J.; MALÁ, L. The comparison between the speed of the serve and the chosen biomechanical parameters of the serve in the training and match conditions in the women volleyball. Antropomotoryka, 2009, roč. 19, č. 45, s. 17-24.

MĚKOTA, K.; BLAHUŠ, P. Motorické testy v tělesné výchově. Praha : SPN, 1983.

MORAS, G.; F., BUSCÀ, B.; PEŇA, J.; RODRÍGUEZ, S.; VALLEJO, L.; FAJARDO, J.; MÚJIKA, I. A comparative study between serve mode and speed and its effectiveness in high-level volleyball tournament. $J$ Sports Med Phys Fitness, 2008, roč. 48, č. 1, s. 31-36.

NUNOME, H.; IKEMAGI, Y.; KOZAKI, R.; APRIANTONO, T.; SANO, S. Segmental dynamics of soccer instep kicking with the preferred and non-preferred leg. Journal of Sports Sciences, 2006, roč. 24, č. 5, s. 529-541.

PŘIDAL, V. Závislost úspešnosti družstva od kvality realizácie herných činností jednotlivca vo volejbale. Telesná výchova a šport, 2001, roč. 11, s. 37-42.

RODRÍGUEZ, S.; MORAS, G.; BUSCÀ, B.; PEŇA, J.; TOUS, J.; VALLEJO, L.; MÚJIKA, I. A comparative study between serve mode and speed and its effectiveness in a high-level volleyball tournament. In 12th Annual Congress of the ECSS, Jyväskylä, Finland, 2007 